\title{
Pengaruh Model Pembelajaran Kooperatif Tipe Think- Pairs-Share Dalam Pembelajaran Matematika Terhadap Kemampuan Pemahaman Konsep Matematis dan Pengembangan Karakter Siswa SMA Kota Sungai Penuh
}

\author{
Maila Sari ${ }^{1}$, Mhmd Habibi ${ }^{2}$, Rahmi Putri ${ }^{3}$ \\ ${ }^{1,2,3}$ Fakultas Tarbiyah dan Ilmu Keguruan IAIN Kerinci
}

\begin{abstract}
Mathematics teachers are required not only to transfer knowledge to learners, but also to shape and develop the character of students in the learning process of mathematics. To be able to grow and develop the character of students required a model of learning that can bring the character formation indicators in the learning process. The learning model that can generate character development indicators is a Think-Pairs-Share (TPS) model of learning. This study aims to determine 1) the ability to understand students' concepts using the TPS learning model and the ability to understand students' concepts that do not use the TPS learning model, 2) the honest character, responsibility, and discipline of students using the TPS learning model and the honest character, and discipline students who do not use the TPS learning model. The result of data analysis shows that: 1) the ability of students' concepts understanding using the TPS learning model is better than the students' concepts comprehension skills that do not use the TPS learning model, 2) the honest character, responsibility, and discipline of students using the TPS learning model more both compared to the honest characters, responsibility and discipline of students who do not use the TPS learning model.
\end{abstract}

Keywords: Think-Pair-Share, Charecters Development, Matemathical Concepts Understanding

\begin{abstract}
Abstrak. Guru matematika dituntut tidak hanya dapat menstransfer ilmu pengetahuan saja kepada peserta didik, namun juga dapat membentuk dan mengembangkan karakter siswa dalam proses pembelajaran matematika. Untuk dapat menumbuhkan dan mengembangkan karakter siswa dibutuhkan suatu model pembelajaran yang dapat memunculkan indikator pembentukan karakter dalam proses pembelajaran. Model pembelajaran yang dapat memunculkan indikator pengembangan karakter adalah model pembelajaran Think-Pairs-Share (TPS). Penelitian ini bertujuan untuk mengetahui 1) kemampuan pemahaman konsep siswa yang menggunakan model pembelajaran TPS dan kemampuan pemahaman konsep siswa yang tidak menggunakan model pembelajaran TPS, 2) karakter jujur, tanggung jawab, dan disiplin siswa yang menggunakan model pembelajaran TPS dan karakter jujur, tanggung jawab dan disiplin siswa yang tidak menggunakan model pembelajaran TPS. Hasil analisis data menunjukkan bahwa: 1) kemampuan pemahaman konsep siswa yang menggunakan model pembelajaran TPS lebih baik dibandingkan dengan kemampuan pemahaman konsep siswa yang tidak menggunakan model pembelajaran TPS, 2) karakter jujur, tanggung jawab, dan disiplin siswa yang menggunakan model pembelajaran TPS lebih baik dibandingkan dengan karakter jujur, tanggung jawab dan disiplin siswa yang tidak menggunakan model pembelajaran TPS.
\end{abstract}

Kata kunci: Think-Pair-Share, Pengembangan Karakter, Pemahaman Konsep Matematis 


\section{PENDAHULUAN}

Pendidikan karakter dan penanaman nilai selama ini hanya dilakukan secara parsial dan dianggap menjadi tanggung jawab dan wewenang guru -guru tertentu. Penanaman nilai-nilai religius dianggap menjadi wilayah guru agama melalui Pendidikan Agama Islam (PAI), sedang penanaman nilai moral, toleransi, nasionalisme diserahkan pada guru PPKn. Guru tersebut secara faktua mempunyai keterbatasan baik dalam hal alokasi waktu maupun otoritas dan kapasitas untuk mengaitkan dengan konstekstual kehidupan, sehingga pendidikan karakter dan penanaman nilai relatif kurang berhasil.

Kekurangberhasilan penanaman nilai dan karakter melalui pendekatan parsial baik disekolah secara khusus maupun masyarakat secara umum, tampak adanya penurunan moral generasi muda kita. Indikator yang sangat nyata adalah semakin meningkatnya para pelajar yang terlibat tawuran, tindakan pidana, terjerat narkoba, pencurian, pemerkosaan, pergaulan bebas dan sebagainya. Kenyaatan ini sudah cukup untuk menjadi alasan guna membenahi atau memperbaiki sistem pendidikan nasional yang saat ini sedang terpuruk. Penanaman karakter yang baik dalam diri peserta didik perlu dilakukan secara serius dan terus-menerus melalui suatu program yang terencana. Upaya tersebut dalam konteks lembaga pendidikan tidak semata-mata menjadi tugas guru pendidikan Agama Islam (PAI) saja tetapi menjadi tugas dan tanggung jawab bersama, termasuk guru Matematika.

Matematika sebagai bagian dari kurikulum pendidikan, diharapkan menjadi sarana bagi pencapaian tujuan pendidikan yang telah ditetapkan yakni adanya perubahan sikap dan tingkah laku anak didik yang mencangkup didalamnya terbentuk pribadi yang berkarakter seeprti komitmen, jujur, kerjasama, kreatif, sopan santun, sikap ilmiah, sikap toleran, demokratis, disamping kemampuan berfikir matematis yang berpijak pada pemikiran yang logis dan sistematis. Pembelajaran matematika selama ini didominasi oleh pengenalan rumus rumus serta konsepkonsep secara verbal, tanpa ada perhatian yang cukup terhadap pemahaman siswa. Selain itu, proses belajar mengajar hampir selalu berlangsung dengan metode ceramah, dengan guru menjadi pusat dari seluruh kegiatan di kelas. Siswa mendengarkan, meniru, atau mencontoh dengan persis sama cara yang diberikan guru tanpa. Inisiatif. Siswa tidak didorong untuk mengoptimalkan potensi dirinya, mengembangkan penalaran maupun kreativitasnya.

Pembelajaran matematika juga seolah-olah dianggap lepas untuk mengembangkan kepribadian siswa. Pembelajaran matematika hanya dianggap menekankan kemmapuan kognitif saja, padahal pengembangan kepribadian sebagai bagian dari kecakapan hidup merupakan tugas semua mata pelajaran di sekolah. Menghadapi kondisi ini pembelajaran matematika harus merubah citra dari pembelajaran yang mekanistik menjadi humanistic yang berkarakter. Dengan demikian pembelajaran matematika diharapkan tidak hanya mampu mengantarkan siswa pada keberhasilan belajar matematika yang diwujudkan dalam bentuk prestasi, tetapi juga adanya perubahan sikap dan karakter.

Berdasarkan hasil observasi dan wawancara yang peneliti lakukan di SMA kota Sungai Penuh, diperoleh informasi bahwa kesadaran akan pentingnya nilai-nilai kehidupan masih sangat kurang di kalangan siswa. Hal itu terlihat ketika jam masuk kelas masih banyak siswa yang telat masuk, masih banyak siswa yang tidak mengerjakan pekerjaan rumah yang diberikan oleh guru, masih adanya budaya mencontek dan berbuat curang saat ujian, ketika jam istirahat banyak siswa yang membuang sampah sembarangan, dan masih banyak siswa yang tidak menaati peraturan dan tidak disiplin terhadap peraturan yang dibuat oleh sekolah. Ketidakdispilinan siswa ini berdampak pada hasil belajar yang diperoleh oleh siswa dan mengakibatkan hasil belajar siswa menjadi sangat rendah.

Untuk mengatasi masalah di atas guru matematika dituntut tidak hanya dapat menstransfer ilmu pengetahuan saja kepada peserta didik, namun juga dapat membentuk dan mengembangkan karakter siswa dalam proses pembelajaran matematika. Untuk dapat menumbuhkan dan mengembangkan karakter siswa dibutuhkan suatu model pembelajaran yang dapat memunculkan indikator pengembangan karakter dalam proses pembelajaran. Model pembelajaran yang dapat memunculkan indikator pengembangan karakter adalah model pembelajaran kooperatif dan model 
pembelajaran kooperatif yang dirasa mampu untuk mengembangkan karakter siswa adalah model pembelajaran Think - Pairs - Share. Langkah-langkah yang ada pada model pembelajaran ThinkPairs-Share diharapkan mampu meningkatkan rasa tanggung jawab, disiplin dan jujur dalam diri siswa. Penerapan model ini diharapkan mampu mengembangkan karakter siswa secara bertahap.

Oleh sebab itu peneliti merasa tertarik untuk meneliti dan memberi judul penelitian ini “ Pengaruh Model Pembelajaran Kooperatif Tipe Think-Pairs-Share Dalam Pembelajaran Matematika Terhadap Kemampuan Pemahaman Konsep Matematis dan Pengembangan Karakter Siswa SMA Kota Sungai Penuh."

Proses pembelajaran merupakan satu rangkaian peristiwa yang kompleks, dimana ada hubungan timbal balik antara siswa dan guru. Dalam proses pembelajaran diharapkan timbul perubahan tingkah laku pada diri siswa. Perubahan tingkah laku dapat mencangkup pengetahuan, keterampilan maupun nilai sikap siswa. Menurut Gagne dalam Ngalim Purwanto (1990:84) menyatakan bahwa belajar terjadi apabila suatu situasi stimulus bersama dengan isi ingatan mempengaruhi siswa sedemikian rupa sehingga perbuatannya berubah dari waktu sebelum ia mengalami situasi itu ke waktu sesudah ia mengalami situasi itu. Menurut Syaiful Bahri Djamarah \& Azwan Zain (1995:38) belajar pada hakikatnya adalah perubahan yang terjadi pada diri seseorang setelah berakhirnya melakukan aktifitas belajar. Hamalik menyatakan bahwa belajar adalah modifikasi atau memperteguh kelakuan melalui pengalaman (learning is defined as the modification or strethening of behavior through experiencing).

Hilgard \& Bower mengemukakan bahwa belajar berhubungan dengan perubahan tingkah laku seseorang terhadap sesuatu situasi tertentu disebabkan oleh pengalamannya yang berulangulang dimana perubahan tingkah laku itu tidak dapat dijelaskan atau dasar kecenderungan respon pembawaan, kematangan atau keadaan-keadaan sesaat seorang. (Pupuh Fathurrohman, 2007:5)

Menurut Agus Suprijono (2009:4) belajar adalah proses sistemik yang dinamis, konstruktif, dan organik, belajar merupakan kesatuan fungsional dari berbagai komponen belajar. Sedangkan menurut Salmeto (2010:2) belajar merupakan suatu proses perubahan tingkah laku sebagai hasil dari interaksi dengan lingkungannya dalam memenuhi kebutuhan hidupnya. Dalam pengertian ini mengarahkan kita pada satu pemahaman bahwa Belajar adalah proses sistemik yang dinamis, konstruktif, dan organik, belajar merupakan kesatuan fungsional dari berbagai komponen belajar. Belajar merupakan suatu proses perubahan tingkah laku sebagai hasil dari interaksi dengan lingkungannya dalam memenuhi kebutuhan hidupnya. Selanjutnya Oemar Hamalik (2008:36) menyatakan bahwa belajar adalah modifikasi atau memperteguh kelakuan melalui pengalaman. (learning is defined as the modification or stengthening of behavior through experiencing).

Berdasarkan pengertian belajar di atas, maka hakikatnya belajar menunjuk ke perubahan tingkah laku si subjek dalam situasi tertentu berkat pengalamannya yang berulang-ulang dan perubahan tingkah laku tersebut tak dapat dijelaskan atas dasar kecenderungan-kecenderungan respons bawaan. Belajar merupakan suatu proses dan kegiatan bukan suatu hasil atau tujuan. Belajar bukan hanya mengingat, akan tetapi lebih luas daripada itu, yakni mengalami. Dalam proses pembelajaran matematika guru dapat mengajar siswa dengan cara melakukan aktifitas pada siswa seperti melatih siswa untuk mampu menyelesaikan permasalahan-permasalahan dalam matematika, dan agar bisa tercipta suasana belajar yang menyenangkan dan memuaskan siswa.

Matematika sebagai salah satu cabang ilmu pengetahuan yang banyak mendasari perkembangan ilmu pengetahuan lain memiliki peran penting dalam kehidupan manusia. Oleh karena itu, matematika dimasukkan dalam kurikulum sekolah. Senada dengan hal tersebut, Erman Suherman (2003:55) menyatakan bahwa matematika sebagai ilmu dasar yang terus berkembang baik materi maupun kegunaannya. Sehingga dalam pembelajaran disekolah harus memperhatikan perkembangan-perkembangannya, baik dimasa lalu, masa sekarang maupun kemungkinankemungkinan untuk masa depan. Jadi alasan perlunya matematika diajarkan disekolah adalah karena matematika sebagai salah satu ilmu dasar yang mempunyai arti penting dalam kehidupan. Tujuan pembelajaran matematika di sekolah adalah agar: (1) Mempersiapkan siswa agar sanggup menghadapi perubahan keadaan di dalam kehidupan yang selalu berkembang, melalui latihan bertindak atas dasar pemikiran secara logis, rasional, kritis, cermat, jujur, efektif dan efisien; (2) Mempersiapkan siswa agar dapat menggunakan matematika dan pola pikir matematika dalam 
kehidupan sehari-hari dan dalam mempelajari berbagai ilmu pengetahuan; (3) Siswa memiliki kemampuan yang dapat dialihgunakan melalui kegiatan matematika; (4) Siswa memiliki pengetahuan matematika sebagai bekal untuk melanjutkan kependidikan menengah; (5) Siswa memiliki keterampilan matematika sebagai peningkatkan dan perluasan dari matematika sekolah dasar untuk dapat digunakan dalam kehidupan sehari-hari; (6) Siswa memiliki pandangan yang cukup luas dan memiliki sikap logis, kritis, cermat dan disiplin serta menghargai kegunaan matematika (Erman Suherman, 2003:58-59)

Dari uraian di atas, jelas bahwa matematika sangat penting untuk dipelajari. Kebanyakan siswa mengalami kesulitan dalam belajar matematika karena matematika memiliki objek yang abstrak. Untuk lebih memudahkan siswa belajar matematika, guru hendaknya memilih strategi yang tepat untuk menyajikan materi dalam pembelajaran.

Model pembelajaran kooperatif tipe TPS adalah merupakan jenis pembelajaran kooperatif yang dirancang untuk mempengaruhi pola interaksi siswa. Model ini pertama kali dikembangkan oleh Frank Lymann dan koleganya di universitas Maryland. Arends (dalam Trianto, 2009:61) menyatakan bahwa TPS merupakan suatu cara yang efektif untuk membuat variasi suasana pola diskusi kelas, dengan asumsi bahwa semua resitasi atau diskusi membutuhkan pengaturan untuk mengendalikan kelas secara keseluruhan, dan prosedur yang digunakan dalam pembelajaran TPS dapat memberi siswa lebih banyak waktu berpikir, untuk merespon dan saling membantu. Pada model pembelajaran ini, guru berperan penting untuk membimbing siswa melakukan diskusi, sehingga tercipta suasana belajar yang aktif, kreatif, dan efektif. Model pembelajaran ini dikembangkan untuk meningkatkan partisipasi siswa di dalam kelas. Dalam penerapannya di kelas, model pembelajaran TPS ini melibatkan tiga langkah, seperti yang dikemukakan oleh Lyman dan kawan-kawan dalam Nurhadi (2004: 67) yang menyatakan bahwa langkah-langkah pembelajaran TPS adalah berfikir (thinking), berpasangan (pairing), dan berbagi (sharing).

1. Langkah 1, Berfikir (Thingking).

Guru mengajukan pertanyaan atau isu yang terkait dengan pelajaran, dan siswa diberi waktu beberapa menit untuk berfikir sendiri mengenai jawaban atau masalah tersebut. Ketika siswa diberikan masalah, siswa akan berusaha secara individu untuk memikirkan solusi atas masalah yang diberikan. Pada tahap ini diharapkan siswa akan mampu memecahkan masalah yang diberikan, sehingga kemampuan pemecahan masalah akan terasah.

2. Langkah 2, Berpasangan (Pairing).

Guru meminta siswa untuk berpasangan dan mendiskusikan apa yang telah dipikirkan. Interaksi selama periode ini dapat menghasilkan jawaban bersama jika suatu pertanyaan telah diajukan atau penyampaian bersama jika suatu isu khusus telah diidentifikasi. Setelah siswa diberikan kesempatan secara individu, siswa selanjutnya diminta untuk berpasangan saling berbagi ide untuk solusi terhadap masalah yang diberikan. pada tahap ini diharapkan siswa mampu mengkomunikasikan atau menyampaikan sesuatu yang diketahui baik berupa konsep, rumus atau strategi penyelesaian masalah.

3. Langkah 3, Berbagi (Sharing).

Guru meminta pasangan-pasangan untuk berbagi atau bekerja sama mengenai apa yang telah mereka bahas. Pada langkah ini. Akan efektif jika guru berkeliling kelas, sehingga seperempat atau separo dari pasangan-pasangan tersebut memperoleh kesempatan melapor. Pada tahap ini diharapkan siswa dapat meningkatkan kemampuan pemecahan masalah dan komunikasi matematis mereka.

Berdasarkan langkah-langkah yang telah dikemukakan di atas, maka langkah-langkah penerapan model TPS dalam proses pembelajaran pada penelitian ini adalah sebagai berikut: (a) Siswa dibagi dalam kelompok yang terdiri dari dua orang (berpasangan) pembentukan kelompok didasarkan pada kemampuan akademik. Ini dilakukan hamya pada pertemuan pertama saja dan untuk selanjutnya siswa duduk berdasarkan pasangannya; (b) Guru menyampaikan informasi mengenai tujuan pembelajaran; (c) Guru membagikan LKS; (d) Siswa mengerjakan LKS dengan model TPS; (e) Guru mengambil secara acak kelompok belajar untuk menyampaikan hasil diskusi mereka; (f) Guru memberikan penghargaan berupa nilai dan pujian; (g) Guru menutup pelajaran 
Penerapan model pembelajaran TPS diharapkan dapat mengembangkan keterampilan berfikir dan menjawab dalam komunikasi antara satu dengan yang lain, serta bekerja saling membantu dalam kelompok kecil. Hal ini sesuai dengan pengertian TPS sendiri sebagaimana yang dikemukakan oleh Lie (2003: 57) menyatakan bahwa TPS adalah pembelajaran yang memberi kesempatan kepada siswa untuk bekerja sendiri dan bekerjasama dengan orang lain. Dalam hal ini guru sangat berperan penting dalam membimbing siswa melakukan diskusi, sehingga tercipta suasana belajar yang lebih hidup, aktif, kreatif, efektif dan menyenangkan.

Pembelajaran kooperatif tipe TPS merupakan tipe yang sederhana dengan banyak keuntungan karena dapat mengoptimalkan partisipasi siswa untuk mengeluarkan pendapatnya dan meningkatkan pengetahuan siswa. selain itu tipe ini memberikan kesempatan pada siswa untuk berfikir, yaitu bekerja sendiri sebelum bekerjasama dengan kelompoknya dan berbagi ide yaitu setiap siswa saling bertukar ide atau informasi yang mereka tahu tentang masalah yang diberikan untuk memperoleh kesepakatan dari penyelesaian soal tersebut. TPS membantu para siswa untuk mengembangkan pemahaman konsep dalam materi pelajaran, mengembangkan kemampuan untuk berbagi informasi dan menarik kesimpulann, serta mengembangkan kemampuan untuk mempertimbangkan nilai-nilai dari suatu materi pelajaran.

Karakteristik model TPS siswa dibimbing secara mandiri, berpasangan, dan saling berbagi untuk menyelesaikan permasalahan. Model ini selain diharapkan dapat menjembatani dan mengarahkan proses belajar mengajar juga mempunyai dampak lain yang sangat bermanfaat bagi siswa. Beberapa akibat yang dapat ditimbulkan dari model ini adalah siswa dapat berkomunikasi secara langsung oleh individu lain yang dapat saling memberi informasi dan bertukar pikiran serta mampu berlatih untuk mempertahankan pendapatnya jika pendapat itu layak untuk dipertahankan. Selain dapat mengembangkan kemampuan pemecahan masalah matematis siswa, penerapan model pembelajaran kooperatif tipe TPS diharapkan mampu meningkatkan komunikasi matematis siswa.

Menurut Kramarski dalam (dalam Ahkmad Jazuli, 2002) mengatakan bahwa untuk mempertinggi kemampuan mengkomunikasikan matematika secara alami adalah dengan memberi kesempatan belajar kepada siswa dalam kelompok kecil dimana mereka dapat berinteraksi. Interaksi antar siswa akan mendorong atau memperkuat pemahaman yang mendalam akan konsepkonsep matematika. Ketika siswa berpikir, merespon, berdiskusi, mengelaborasi, menulis, membaca, mendengarkan, dan menemukan konsep-konsep matematika, mereka mempunyai berbagai keuntungan, yaitu berkomunikasi untuk belajar matematika dan belajar untuk berkomunikasi secara matematik (NCTM, 2000). Kelompok berpasangan ini memungkinkan semua siswa untuk berinteraksi dengan optimal, mengembangkan semangat kebersamaan, menumbuhkan minat belajar dan meningkatkan komunikasi yang efektif dalam pembelajaran. Hal ini diartikan bahwa proses komunikasi yang baik memungkinkan siswa untuk membangun pengetahuan matematikanya. Model Pembelajaran TPS merupakan model pembelajaran kooperatif yang beranggotakan dua orang (pasangan), pasangan ini diharapkan mampu berinteraksi dan mendorong siswa untuk memperkuat pemahamannya yang mendalam mengenai konsep-konsep matematika.

Model pembelajaran kooperatif tipe TPS dilandasi oleh teori belajar Konstruktivisme yang menyatakan bahwa siswa harus menemukan sendiri dan menstranformasi informasi kompleks, mengecek informasi baru dengan aturan-aturan lama dan merevisinya apabila aturan- aturan itu tidak lagi sesuai. Bagi siswa agar benar-benar memahami dan menerapkan pengetahuan, mereka harus menemukan segala sesuatu untuk dirinya. Teori ini juga menyatakan bahwa agar siswa benar-benar memahami dan dapat menerapkan pengetahuan, mereka harus bekerja memecahkan, menemukan segala sesuatu untuk dirinya, berusaha bersusah payah dengan ide-ide (Jamil, 2013: 22). Menurut teori konstruktivisme siswa sebagai pemain dan guru sebagai fasilitator. Guru mendorong siswa untuk mengembangkan potensi secara optimal, siswa belajar bukanlah menerima paket-paket konsep yang sudah dikemas oleh guru melainkan siswa sendiri yang mengemasinya. Bagian terpenting dari teori ini adalah bahwa dalam proses pembelajaran siswalah yang harus aktif mengembangkan kemampuan mereka, bukan guru atau orang lain.

Pembelajaran kooperatif tipe Think-Pairs-Share memiiki kelbihan dan kelemahan. Adapun kelebihan model pembelajaran kooperatif tipe TPS menurut Huda (Dalam Kusmiati, 2011:136) 
yaitu 1) TPS memungkinkan siswa untuk merumuskan dan mengajukan pertanyaan-pertanyaan mengenai materi yang diajarkan karena secara tidak langsung memperoleh contoh pertanyaan yang diajukan oleh guru, serta memperoleh kesempatan untuk memikirkan materi yang diajarkan, 2) Siswa akan terlatih menerapkan konsep karena bertukar pendapat dan pemikiran dengan temannya untuk mendapatkan kesepakatan dalam memecahkan masalah, 3) Siswa lebih aktif dalam pembelajaran karena menyelesaikan tugasnya dalam kelompok, dimana tiap kelompok hanya terdiri dari 2 orang, 4) Siswa memperoleh kesempatan untuk mempersentasikan hasil diskusinya dengan seluruh siswa sehingga ide yang ada menyebar, 5) memungkinkan guru untuk lebih banyak memantau siswa dalam proses pembelajaran. Sedangkan kelemahan model pembelajaran kooperatif tipe TPS adalah waktu yang terbatas, sedangkan jumlah kelompok yang terbentuk banyak.

Menurut Hudoyo pemahaman konsep merupakan salah satu tujuan penting dalam pembelajaran matematika. Konsep-konsep merupakan pilar-pilar pembangun untuk berfikir yang lebih tinggi. Dengan mengenal konsep dan struktur yang tercangkup dalam bahan yang sedang dibicarakan, anak akan memahami materi yang harus dikuasainya itu. Ini menunjukkan bahwa materi yang mempunyai pola atau struktur tertentu akan lebih mudah dipahami dan diingatnya. Pemahaman konsep matematis merupakan kompetensi yang ditunjukkan siswa dalam memahami konsep. Indikator pemahaman konsep menurut Depdiknas adalah: (a) Menyatakan ulang sebagian konsep; (b) Mengklasifikasikan objek menurut sifat-sifat tertentu sesuai dengan konsepnya; (c) Memberi contoh dan bukan contoh dari suatu konsep; (d) Menyajikan konsep dalam berbagai bentuk representasi matematis; (e) Mengembangkan syarat perlu atau syarat cukup dari suatu konsep; (f) Menggunakan dan memanfaatkan serta memilih prosedur atau operasi tertentu; (g) Mengaplikasikan konsep atau logaritma pada pemecahan masalah.

Sementara itu, Karakter diartikan sebagi tabiat, sifat-sifat kejiwaan, akhlak atau budi pekerti yang membedakan seseorang dengan yang lain. Orang yang berkarakter adalah orang yang berkepribadian, berperilaku, bersifat, bertabiat, atau berwatak tertentu, dan watak tersebut yang membedakan dirinya dengan orang lain. Menurut Lickona, karakter mulia (good character) meliputi pengetahuan tentang kebaikan, lalu menimbulkan komitmen (niat) terhadap kebaikan, dan akhirnya benar-benar melakukan kebaikan (Suyadi, 2012:5) Dengan kata lain, karakter mengacu kepada serangkaian pengetahuan (cognitives), sikap (attitides), dan motivasi (motivations), serta perilaku (behaviors) dan keterampilan (skills).

Karakter menurut Pusat Kurikulum (2010) adalah watak yang terbentuk dari nilai, moral, dan norma yang mendasari cara pandang, berfikir, sikap, dan cara bertindak seseorang serta yang membedakan dirinya dari orang lainnya. Karakter merupakan kunci keberhasilan individu. Hal ini dibuktikan dari beberapa studi yang menunjukkan bahwa keberhasilan seseorang ditentukan oleh kualitas karakternya sebesar $80 \%$ dan hanya 20\% ditentukan oleh kemampuan akademiknya. Tidaklah terlalu berlebihan jika dikatakan karakter bangsa terwujud dari karakter seseorang yang menjadi anggota masyarakat bangsa tersebut. Soejadi (2009) menjelaskan bahwa membangun pendidikan karakter bangsa merupakan strategi, pendekatan, metode, dan teknik dengan menyadari potensi Illahi dalam diri generasi berkarakter untuk mencapai pribadi yang sadar akan nilai kehidupan bersama, sadar akan kelebihan dan kekurangan diri, berkemampuan, cerdas, mampu berkebiasaan baik, berfikir dan bertindak positif yang merupakan keanekaragaman elemen suku bangsa, keluarga, atau kelompok warga atau individu, atau warga bangsa yang merupakan satu kesatuan. Kenyataan yang terjadi kini, justru sekolah pun abai dengan pembentukan karakter. Beberapa pakar pendidikan mengatakan bahwa penyebab utama gagalnya dunia pendidikan membangun manusia yang berkualitas adalah disebabkan terlalu menekankan pendidikan akademik (kognitif) dan mengecilkan pentingnya pendidikan karakter (afektif, kecerdasan emosi).

Menurut T. Ramli pendidikan karakter memiliki esensi dan makna yang sama dengan pendidikan moral dan pendidikan akhlak yang bertujuan membentuk pribadi anak, supaya menjadi manusia, warga masyarakat dan warga Negara yang baik (Hamdani, 2013:33). Dari pengertian di atas dapat dipahami bahwa karakter identik dengan akhlak, sehingga karakter merupakan nilai-nilai perilaku manusia yang universal yang meliputi seluruh aktivitas manusia, baik dalam rangka berhubungan dengan Tuhannya, dengan dirinya, dengan sesama manusia, maupun dengan 
lingkungannya, yang terwujud dalam pikiran, sikap, perasaan, perkataan, dan perbuatan berdasarkan norma-norma agama, hokum, tata karma, budaya, dan adat istiadat.

Dalam penelitian ini karakter yang akan diukur adalah karakter jujur, disiplin, dan tanggung jawab. Adapun indikator sikap jujur adalah 1) tidak menyontek dalam mengerjakan ujian/tugas, 2) tidak menjadi plagiat (mengambil/menyalin) karya orang lain tanpa menyebutkan sumber, 3) mengungkap perasaan apa adanya, 4) siswa menyatakan sikap benar atau salah terhadap materi, 5) siswa berani dan percaya diri menjawab pertanyaan guru, 6) siswa tenang dan paham mengerjakan tugas dari guru. Sikap disiplin dalam proses pembelajaran dikelas dapat ditunjukkan dengan dating tepat waktu, mmeperhatikan penjelasan dan pendapat guru maupun teman, dan mengikuti kegiatan dengan tertip.indikator sikap disiplin adalah, 1) datang tepat waktu, 2) patuh dan tertib terhadap aturan bersama atau sekolah, 3) mengikuti kaidah berbahasa tulis yang baik dan benar.

Sikap tanggung jawab adalah sikap dan perilaku untuk melaksanakan tugas dan kewajiban sbagaimana seharusnya dilakukan, baik terhadap diri sendiri, teman, maupun guru. Dalam proses pembelajaran sikap tangung jawab dapat ditunjukkan dengan acara mengerjakan tugas sesuai dengan yang ditentukan, berperan aktif dalam kelompok atau berani menanggung resiko atas perbuatan yang dialkukan. Indikator karakter tanggung jawab adalah, 1) melaksanakan tugas individu yang baik, 2) menerima resiko dari tindakan yang dilakukan, 3) tidak menyalahkan/menuduh orang lain tanpa bukti yang akurat, 4) mengembalikan barang yang dipinjam, 5) mengakui dan meminta maaf atas kesalahan yang dilakukan, 6) menepati janji, 7) tidak menyalahkan orang lain untuk kesalahan tindakan kita sendiri, 8) melaksanakan apa yang pernah dikatakan tanpa disuruh/diminta.

\section{METODE}

Penelitian ini dilaksanakan dengan menggunakan metode Quasi Experiment (eksperimen semu) dengan pendekatan kuantitatif. Menurut Arikunto (1998:3) penelitian eksperimen adalah suatu cara untuk mencari hubungan sebab akibat dari suatu perlakuan. Terdapat dua kelompok sampel pada penelitian ini yaitu kelompok eksperimen yang melaksanakan pembelajaran dengan model kooperatif tipe TPS dan kelompok kontrol dengan pembelajaran konvensional. Penelitian ini menggunakan dua kelas yaitu kelas eksperimen dan kelas kontrol. Variabel dalam penelitian ini terdiri dari variabel bebas yaitu penggunaan model pembelajaran kooperatif tipe TPS dan pembelajaran konvensional, variabel terikat yaitu kemampuan pemahaman konsep matematis siswa dan pembentukan karakter siswa.

Desain yang digunakan untuk melihat pengaruh penerapan model pembelajaran kooperatif tipe TPS terhadap kemampuan pemahaman konsep matematis dan pembentukan karakter siswa adalah desain Randomized Control Group Only Design.

\section{Populasi dan Sampel}

Populasi dalam penelitian ini adalah seluruh siswa yang terdaftar di SMA Kota Sungai Penuh tahun pelajaran 2017/2018.

Tabel 4. Data Populasi Kelas X SMA Kota Sungai Penuh

\begin{tabular}{|c|c|c|c|}
\hline No & Nama Sekolah & Kelas & Jumlah Siswa \\
\hline \multirow{5}{*}{1} & \multirow{5}{*}{ SMA Negeri 1 Kota Sungai Penuh } & X A & 30 orang \\
\hline & & $\mathrm{X} \mathrm{B}$ & 30 orang \\
\hline & & $\mathrm{X} \mathrm{C}$ & 30 orang \\
\hline & & X D & 30 orang \\
\hline & & $\mathrm{XE}$ & 30 orang \\
\hline \multirow{4}{*}{2} & \multirow{4}{*}{ SMA Negeri 2 Kota Sungai Penuh } & $\mathrm{X} \mathrm{A}$ & 28 orang \\
\hline & & X B & 26 orang \\
\hline & & $\mathrm{XC}$ & 26 orang \\
\hline & & $\mathrm{XD}$ & 22 orang \\
\hline \multirow{2}{*}{3} & \multirow{2}{*}{ SMA Negeri 3 Kota Sungai Penuh } & X A & 16 orang \\
\hline & & X B & 16 orang \\
\hline
\end{tabular}




\begin{tabular}{|c|c|c|c|}
\hline \multirow{4}{*}{4} & \multirow{4}{*}{ SMA Negeri 4 Kota Sungai Penuh } & X A & 24 orang \\
\hline & & X B & 24 orang \\
\hline & & $\mathrm{X} \mathrm{C}$ & 24 orang \\
\hline & & X D & 24 orang \\
\hline & Jumlah & & 380 orang \\
\hline
\end{tabular}

Sumber: Guru Matematika SMA Negeri Kota Sungai Penuh

Untuk menentukan sampel pada penelitian ini digunakan teknik random Sampling. Sampel yang dipilih haruslah sampel yang representatif sehingga menggambarkan keseluruhan karakteristik dari satu populasi. Untuk menentukan kelas sampel pada penelitian ini dilakukan langkah-langkah sebagai berikut.

1. Mengumpulkan nilai hasil tes matematika siswa SMA Kelas X sekota Sungai Penuh tahun 2016/2017.

2. Menguji kesamaan rata-rata dengan malakukan langkah-langkah sebagai berikut:

3. Melakukan uji normalitas untuk tiap kelompok data. Uji normalitas bertujuan untuk mengetahui apakah data berdistribusi normal atau tidak dengan menggunakan uji Kolmogorov Smirnov. Hasil uji normalitas dapat dilihat pada Lampiran II. Berdasarkan uji normalitas terlihat bahwa nilai Kolmogorov Smirnov yang diperoleh setiap anggota populasi adalah lebih besar dari taraf nyata $\alpha=0,05$. Jadi disimpulkan bahwa anggota populasi berdistribusi normal. Pada tabel 5 dapat dilihat hasil dari output normalitas.

Tabel 5. Uji Normalitas Data Nilai Populasi Siswa SMA Negeri Kota Sungai Penuh

\begin{tabular}{cccc}
\hline No & Nama Sekolah & Sig & Ket. \\
\hline 1. & $\mathrm{X}_{\mathrm{A}}$ SMAN 1 Sungai Penuh & 0,198 & Normal \\
\hline 2. & $\mathrm{X}_{\mathrm{B}}$ SMAN 1 Sungai Penuh & 0,140 & Normal \\
\hline 3. & $\mathrm{X}_{\mathrm{C}}$ SMAN 1 Sungai Penuh & 0,145 & Normal \\
\hline 4. & $\mathrm{X}_{\mathrm{D}}$ SMAN 1 Sungai Penuh & 0,172 & Normal \\
\hline 5. & $\mathrm{X}_{\mathrm{E}}$ SMAN 1 Sungai Penuh & 0,092 & Normal \\
\hline 6. & $\mathrm{X}_{\mathrm{A}}$ SMAN 2 Sungai Penuh & 0,082 & Normal \\
\hline 7. & $\mathrm{X}_{\mathrm{B}}$ SMAN 2 Sungai Penuh & 0,200 & Normal \\
\hline 8. & $\mathrm{X}_{\mathrm{C}}$ SMAN 2 Sungai Penuh & 0,129 & Normal \\
\hline 9. & $\mathrm{X}_{\mathrm{D}}$ SMAN 2 Sungai Penuh & 0,116 & Normal \\
\hline 10. & $\mathrm{X}_{\mathrm{A}}$ SMAN 3 Sungai Penuh & 0,136 & Normal \\
\hline 11. & $\mathrm{X}_{\mathrm{B}}$ SMAN 3 Sungai Penuh & 0,200 & Normal \\
\hline 12. & $\mathrm{X}_{\mathrm{A}}$ SMAN 4 Sungai Penuh & 0,200 & Normal \\
\hline 13. & $\mathrm{X}_{\mathrm{B}}$ SMAN 4 Sungai Penuh & 0,068 & Normal \\
\hline 14. & $\mathrm{X}_{\mathrm{C}}$ SMAN 4 Sungai Penuh & 0,093 & Normal \\
\hline 15. & $\mathrm{X}_{\mathrm{D}}$ SMAN 4 Sungai Penuh & 0,200 & Normal \\
\hline
\end{tabular}

4. Melakukan uji homogenitas variansi dengan menggunakan uji Levene untuk mengetahui apakah populasi mempunyai variansi yang homogen atau tidak. Hasil uji Levene dapat dilihat pada Lampiran III. Dari hasil uji homogenitas diperoleh nilai signifikansi 0,0636 (lebih besar dari taraf nyata 0,05$)$. Artinya populasi memiliki variansi yang homogen. Pada tabel 6 dapat dilihat hasil dari output homogenitas varians.

Tabel 6. Uji Normalitas Data Nilai Populasi Siswa SMA Negeri Kota Sungai Penuh

\begin{tabular}{cccc}
\hline Levene Statistic & df1 & df2 & Sig. \\
\hline 0.830 & 14 & 363 & .636 \\
\hline
\end{tabular}

5. Melakukan uji kesamaan rata-rata untuk melihat apakah populasi mempunyai kesamaan ratarata atau tidak dengan menggunakan uji ANAVA satu arah. Hasil uji Anava satu arah dapat dilihat pada Lampiran III. Nilai signifikansi kelompok populasi diperoleh 0,898 (lebih besar dari taraf nyata 0,05$)$, sehingga dapat disimpulkan bahwa setiap kelas memiliki kesamaan ratarata untuk taraf nyata $\alpha=0,05$.

Tabel 7. Uji Kesamaan Rata-Rata Nilai Populasi Siswa SMA Negeri Kota Sungai Penuh

\begin{tabular}{cccccc}
\hline & Sum of Squares & df & Mean Square & F & Sig. \\
\hline Between Groups & 2469.110 & 14 & 176.365 & 0.556 & 0.898 \\
\hline
\end{tabular}

Available online at Journal homepage: ejournal.iainkerinci.ac.id/index.php/edumatika Email: edumatika@iainkerinci.ac.id 


\begin{tabular}{cccc}
\hline Within Groups & 115075.070 & 363 & 317.011 \\
\hline Total & 117544.180 & 377 & - \\
\hline
\end{tabular}

6. Karena semua kelompok populasi mempunyai kesamaan nilai rata-rata, maka pengambilan sampel dilakukan dengan teknik Random Sampling yaitu dengan melakukan pengundian menggunakan gulungan kertas yang berjumlah 15 buah yang berisi nama kelas dan sekolah. Kemudian dilakukan pengambilan secara acak dengan mengambil 2 potongan kertas sekaligus. Kelas yang terbuka pertama adalah kelas $\mathrm{X}_{\mathrm{A}}$ SMA Negeri 2 Sungai Penuh ditetapkan sebagai kelas eksperimen dan kelas yang terbuka kedua adalah kelas $\mathrm{X}_{\mathrm{C}}$ SMA Negeri 3 Sungai Penuh sebagai kelas kontrol.

\section{HASIL PENELITIAN}

Setelah dilakukan tes kemampuan pemahaman konsep matematis dan tes pengembangan karakter siswa pada kelas eksperimen dan kelas kontrol, diperoleh data tentang kemampuan pemahaman konsep matematis dan pengembangan karakter siswa yang menggunakan model pembelajaran kooperatif tipe Think-Pairs-Share (TPS) dan siswa kelas kontrol yaitu siswa yang menggunakan metode pembelajaran secara konvensional. Berikut ini adalah deskripsi data hasil tes kemampuan pemahaman konsep matematis dan pengembangan karakter siswa kelas eksperimen dan kelas kontrol.

\section{Data Tes Kemampuan Pemahaman Konsep Matematis Siswa}

Setelah dilakukan tes akhir diperoleh data tentang kemampuan pemahaman konsep matematika siswa kelas eksperimen yaitu kelas yang diajarkan menggunakan model pembelajaran kooperatif tipe Think-Pairs-Share (TPS). Data mengenai nilai rata-rata kemampuan konsep siswa kelas eksperimen dapat dilihat pada Tabel 15.

Tabel 8. Rata-rata Kemampuan Pemahaman Konsep Matematis Siswa Kelas Eksperimen dan Kelas Kontrol

\begin{tabular}{ccc}
\hline & Rata-rata Skor (Eksperimen) & Rata-Rata Skor (Kontrol) \\
\hline $\mathrm{X}$ & 16,25 & 15,38 \\
\hline $\mathrm{S}$ & 2,17 & 2,1 \\
\hline $\mathrm{S}^{2}$ & 4,71 & 4,41 \\
\hline
\end{tabular}

Berdasarkan data di atas, diketahui bahwa perolehan rata-rata skor pemahaman konsep matematis siswa pada kelas yang menggunakan pembelajaran kooperatif tipe TPS lebih tinggi daripada kelas yang menggunakan pembelajaran secara konvensional. Model pembelajaran kooperatif tipe Think-Pairs-Share (TPS) adalah sebuah model pembelajaran yang membuat siswa terlibat secara aktif dalam proses pembelajaran. Pembelajaran kooperatif tipe TPS memiliki strategi kerja kelompok yang melibatkan pasangan untuk menyelesaikan masalah atau tugas yang diberikan oleh guru sehingga dengan menerapkan pembelajaran kooperatif tipe TPS dapat membantu siswa memahami konsep karena siswa dapat saling bekerjasama dengan temannya dalam memahami konsep dalam materi yang dipelajari, sehingga tidak ada siswa yang pasif. Selain itu, siswa juga dilatih untuk berani mengemukakan pendapat dan berdiskusi dengan pasangannya untuk memperoleh jawaban yang tepat dengan saling bertukar pikiran maupun pendapat sehingga setiap permasalahan matematika khususnya dalam pemahaman konsep matematis siswa terlihat lebih mudah.

Pada pembelajaran konvensional, dalam proses pembelajarannya kurang melibatkan siswa secara aktif yaitu siswa hanya mendengarkan dan mencatat apa yang dijelaskan oleh guru sehingga siswa akan mudah jenuh. Pada proses pembelajarannya siswa tidak dituntut untuk menemukan sendiri konsep- konsep melainkan mendapatkannya dari penjelasan guru dan akibatnya siswa mudah melupakan konsep-konsep yang telah diberikan. 


\section{Data Tes Pengembangan Karakter Siswa}

Tes pengembangan karakter siswa dilakukan untuk melihat pengembangan karakter siswa yang menggunakan model pembelajaran TPS dengan ssiwa yang menggunakan model pembeljaran konvensional. Karakter yang dilihat disini adalah karakter jujur, disiplin dan tanggung jawab. Data mengenai Skor rata-rata pengembangan karakter siswa dapat dilihat pada tabel 16.

Tabel 9. Rata-Rata Skor Angket Pengembangan Karakter Siswa

\begin{tabular}{ccc}
\hline & $\begin{array}{c}\text { Rata-Rata Skor Angket } \\
\text { (Eksperimen) }\end{array}$ & $\begin{array}{c}\text { Rata-Rata Skor Angket } \\
\text { (Kontrol) }\end{array}$ \\
\hline $\mathrm{X}$ & 78,2 & 62,4 \\
\hline $\mathrm{S}$ & 2,17 & 4,1 \\
\hline $\mathrm{S}^{2}$ & 4,71 & 16,1 \\
\hline
\end{tabular}

Berdasarkan data diatas, terlihat bahwa skor rata-rata angket pengembangan karakter siswa yang menggunakan model pembelajaran TPS lebih tinggi dibandingkan dengan siswa yang menggunakan model pembelajaran secara konvensional. Hal itu dikarenakan pada pembelajaran yang menggunakan model pembelajaran TPS, siswa dilatih untuk bersikap jujur terhadap pasangannya dalam menjawab pertanyaan yang diajukan oleh pasangannya, selain itu siswa juga diajarakan untuk bersikap disiplin dan tanggung jawab terhadap tugas yang diberikan kepadanya. Rasa tanggung jawab tersebut terlihat ketika siswa yang pintar dengan penuh rasa tanggung jawab mengajarkan siswa yang kurang pintar tentang materi yang sedang dibahas. Sedangkan kedisiplinan siswa tergambar ketika siswa menyelesaikan maslah yang diberikan oleh guru tepat pada watu yang telah ditentukan.

\section{PEMBAHASAN}

\section{Kemampuan Pemahaman Konsep Matematis Siswa pada Kelas Eksperimen}

Dari hasil penelitian diperoleh bahwa kemampuan pemahaman konsep siswa yang diajar dengan model pembelajaran kooperatif tipe Think-Pairs-Share lebih tinggi daripada kemampuan pemahaman konsep matematis siswa yang diajar dengan model pembelajaran konvensional. Hal itu dikarenakan model pembelajaran kooperatif tipe TPS mengarahkan siswa terlebih dahulu melakukan kegiatan berpikir, merefleksikan dan menyusun ide-ide untuk dapat menyelesaikan soal yang diberikan oleh guru secara individu kemudian baru dilanjutkan dengan berdiskusi dengan pasangannya.

Pada saat berpasangan siswa akan saling bertukar pendapat atau ide-ide mereka terhadap masalah yang diberikan. Hasil pengamatan ketika pembelajaran pada kelas eksperimen dengan menggunakan model Think-Pairs-Share adalah siswa dapat berinteraksi dengan pasangannya dalam memecahkan masalah. Pada tahap think siswa memikirkan masalah yang diberikan oleh guru secara individu, terlihat bahwa sebagian siswa ada yang hanya berfikir saja dan sebagian siswa ada yang mencoba mencari jawaban. Pada tahap ini mengurangi siswa untuk berbicara, karena siswa sibuk memikirkan jawaban dari masalah yang diberikan oleh guru. Tahap pairs adalah tahap dimana siswa berpasangan, pada kegiatan ini terlihat siswa mendiskusikan dengan pasangannya tentang jawaban yang diperoleh pada tahap think. Langkah diskusi yang diterapkan agar siswa yang pandai dapat membantu temannya yang lemah dalam pembelajaran dan dapat berbagi dan bekerja sama dengan pasangannya. Siswa merumuskan hasil jawaban dan mendiskusikan jawaban yang tepat. Tahap share siswa mempresentasikan hasil yang telah didiskusikan dengan pasangannya, guru menunjuk salah satu pasangan kelompok untuk maju kedepan kelas mempresentasikan hasil jawaban untuk menyatukan pendapat dan siswa lainnya ikut mendiskusikan dan menyimpulkan jawaban yang benar.

Kemampuan pemahaman konsep yang diperoleh siswa pada pembelajaran Think-PairsShare membuat siswa dapat memahami masalah, merencanakan penyelesaian, melaksanakan penyelesaian dan membuat kesimpulan terhadap penyelesaian masalah tersebut. Hal tersebut di atas 
senada dengan pendapat Lyman yang mengemukakan bahwa TPS membantu para siswa untuk mengembangkan pemahaman konsep dalam materi pelajaran, mengembangkan kemampuan untuk berbagi informasi dan menarik kesimpulann, serta mengembangkan kemampuan untuk mempertimbangkan nilai-nilai dari suatu materi pelajaran.

Hasil pengamatan ketika pembelajaran pada kelas eksperimen dengan menggunakan model pembelajaran koopertife tipe Think-Pairs-Share adalah semua siswa aktif dalam pembelajaran dan siswa tidak merasa bosan dengan pembelajaran karena dalam pembelajaran ini siswa yang kurang pandai akan dibantu oleh temannya yang lebih pandai sehingga siswa tersebut termotivasi dalam kegiatan pembelajaran. Selain itu sebelum siswa memulai pembelajaran siswa selalu diingatkan kembali tentang pelajaran sebelumnya.

Siswa yang diajarkan dengan menggunakan model pembelajaran koopertife tipe ThinkPairs-Share terlebih dahulu sudah diberikan arahan-arahan dalam menjawab masalah yang akan diberikan. Pembagian pasangan dilakukan secara heterogen, diamna siswa yang pandai akan dipasangkan dengan siswa yang kurang pandai. Pembagian pasangan pada model pembelajaran koopertife tipe Think-Pairs-Share didasarkan pada rangking yang diperoleh oleh siswa. Siswa rangking 1 akan dipasangkan dengan siswa rangking 22, siswa rangking 2 akan dipasangkan dengan siswa rangking 21 dan begiru seterusnya. Kepada siswa tersebut dan siswa tersebut sudah terbiasa berinteraksi dengan teman sekelompok yang lebih pintar, sehingga siswa yang kurang pintar termotivasi dan aktif menyatakan ide-ide dan bertanya tentang apa yang belum diketahuinya. Diskusi bersama pasangan membuat siswa pintar akan lebih aktif dalam proses pembelajaran. Siswa yang lebih pintar dapat membantu siswa yang kurang pintar.

Hasil tes kemampuan pemahaman konsep matematis siswa menunjukkan siswa sudah biasa menyelesaikan soal tes kemampuan pemahaman konsep yang diberikan oleh guru. Siswa sudah mampu mengklasifikasikan objek menurut sifat-sifat tertentu sesuai dengan konsepnya, dapat menggunakan dan memanfaatkan serta memilih prosedur atau operasi tertentu, dan dapat mengaplikasikan konsep ke algoritma pemecahan masalah.

\section{Kemampuan Pemahaman Konsep Matematis Siswa pada Kelas Kontrol}

Kemampuan pemahaman konsep matematis siswa yang tidak menggunakan model pembelajaran koopertaif tipe Think-Pairs-Share jauh berbeda dengan kemampuan pemahaman konsep siswa yang menggunakan pembelajaran model pembelajaran koopertaif tipe Think-PairsShare. Hal ini dapat dilihat pada hasil tes akhir kelas kontrol, dari tes tersebut diperoleh rata-rata 16,1. Pada kelas kontrol konsep diberikan dan dijelaskan oleh guru secara langsung melalui metode caramah dan tanya jawab. Setelah informasi diberikan, siswa diberi kesempatan untuk mencatat dan bertanya dan mengerjakan soal latihan yang ada pada LKS. Hal ini menyebabkan pembelajaran hanya didominasi oleh guru sehingga kemampuan pemahaman konsep matematis siswa kurang terasah karena siswa hanya menghafal materi yang diberikan oleh guru. Dalam pembelajaran secara konvensional ini, terlihat bahwa hanya beberapa orang saja yang mau bertanya dan memberi tanggapan tentang materi pelajaran. Apabila ditanya atau diminta menyelesaikan konsep, siswa tidak mampu menjelaskan konsep tersebut dengan bahasanya sendiri.

Pada pembelajaran konvensional penjelasan materi diberikan oleh guru kemudian guru memberikan contoh soal dan diikuti soal latihan dan pemberian tugas di rumah. Hasil pengamatan di kelas kontrol adalah masih banyak siswa yang kurang memahami soal tentang kemampuan pemahaman konsep matematika. Siswa hanya bisa menjawab soal yang mirip dengan contoh soal yang diberikan oleh guru. Siswa hanya terbiasa menyelesaikan soal secara individu, siswa tidak dibiasakan untuk bekerja secara berpasangan atau kelompok. Sehingga ketika diberikan tes kemampuan pemahaman konsep oleh guru, hanya beberapa orang siswa saja yang mampu menyelesaikannya dengan baik. Siswa yang lainnya terlihat kesulitan dalam menyelesaikan soal tersebut diakrenakan tidak pernah dicontohkan oleh guru mereka di papan tulis. Sehingga mereka menyelesaiaknnya terkesan asal-asalan dan hal ini tentunya menyebabkan kemampuan pemahamann konsep matematika siswa kelas kontrol menjadi rendah jika dibandingakn dengan kelas ekspeimen. 


\section{Perbedaan Kemampuan Pemahaman Konsep Matematis Siswa}

Perbedaan yang terjadi antara siswa kelas eksperimen dan kelas kontrol dalam menjawab soal dikarenakan pembelajaran yang diterapkan di kelas. jika pada kelas eksperimen diterapkan model pembelajaran kooperatif tipe Think-Pairs Share, pembelajaran yang dilakukan pada kelas kontrol terlalu terpusat pada guru, guru mendominasi pembelajaran sehingga sedikit memberikan kesempatan kepada siswa untuk terlibat secara aktif dalam proses pembelajaran. Guru menjelaskan materi kemudian memberikan contoh soal dan penyelesaiannya. Proses pembelajaran seperti ini akan membiasakan siswa untuk menghafal konsep yang diberikan oleh guru dan tidak melekat dengan baik dalam ingatan siswa. Jika dihapakan pada soal yang sedikit berbeda siswa akan mengalami kesulitan dan akan menganggap bahwa mereka belum pernah mempelajarinya.

Berdasarkan skor tes kemampuan pemahaman konsep matematis siswa diketahui bahwa rata-rata skor kemampuan pemecahahan masalah matematis siswa kelas eksperimen 16,25 dan ratarata skor tes akhir siswa kelas kontrol adalah 15,83. Dari data tersebut dapat dikatakan bahwa ratarata skor kemampuan pemahaman konsep matematis siswa kelas ekperimen pada materi fungsi lebih tinggi dari pada kelas kontrol. Hal terjadi karena semua siswa kelas ekperimen sudah terbiasa dengan model pembelajaran kooperatif tipe Think-Pairs-Share dimana langkah-kangkah TPS itu sendiri terdapat pada indikator kemampuan pemahaman konsep matematis sehingga kemampuan siswa untuk memahami konsep matematis akan semakin terlatih.

Sedangkan pada kelas kontrol siswa hanya dibiasakan menerima apa yang diberikan oleh guru. Seharusnya siswa tidak dilatih untuk menerima apa yang diberikan oleh gurunya semata, namun siswa seharusnya diajak untuk dapat memecahkan, menemukan dengan saling berbagi ideide dengan temannya agar kemampuan pemahaman konsepnya dapat terasah dengan baik. Hal ini sesuai dengan teori yang dikemukakan oleh Jamil yang menyatakan bahwa agar siswa benar-benar memahami dan dapat menerapkan pengetahuan, mereka harus bekerja memecahkan, menemukan segala sesuatu untuk dirinya, berusaha bersusah payah dengan ide-ide.

Hasil tes kemampuan pemahaman konsep matematis siswa pada kelas kontrol kurang bisa menjawab soal tes kemampuan pemhaman konsep matematis yang diberikan oleh guru. Hanya beberapa orang saja yang bisa mengerjakannya. Siswa yang lainnya merasa kesulitan dalam menyelesaiakn soal yang diberikan oleh guru, hal itu dikarenakan soal yang diberikan tidak pernah dicontohkan oleh guru mereka, sehingga siswa tersebut hanya diam dan mengaharap jawaban yang diberikan tema.

\section{Pengembangan Karakter Siswa yang Menggunakan Model Pembelajaran Kooperatif Tipe Think-Pairs-Share}

Pendidikan harus dapat menghasilkan insan-insan yang memiliki karakter mulia, di samping memiliki kemampuan akademik dan keterampilan yang memadai. Untuk itulah maka segala usaha untuk mengintegrasikan pendidikan karakter dalam setiap proses pembelajaran dan kegiatan belajar-mengajar menjadi sangat penting untuk mewujudkan dan membentuk manusia yang berkarakter. Karakter adalah watak, tabiat, akhlak, atau kepribadian seseorang yang terbentuk dari hasil internalisasi berbagai kebajikan (virtues) yang diyakini dan digunakan sebagai landasan untuk cara pandang, berpikir, bersikap, dan bertindak. Kebajikan terdiri atas sejumlah nilai, moral, dan norma, seperti jujur, berani bertindak, dapat dipercaya, dan hormat kepada orang lain.

Model pembelajaran kooperatif tipe Think Pair Share merupakan model pembelajaran yang dikembangkan oleh Frank Lyman dari Univeristas Maryland. Pada saat guru mempresentasikan sebuah pelajaran di kelas, siswa duduk berpasangan didalam tim mereka. Tiga tahapan dalam model pembelajaran ini adalah: (1) Think. Guru mengajukan pertanyaan kepada siswa, dan pada tahap ini siswa diminta untuk memikirkan sendiri atas jawaban pertanyaan itu. (2) Pair. Setelah siswa diminta memikirkan sendiri atas jawaban dari pertanyaan yang diberikan oleh guru, pada tahap ini siswa berpasangan dengan pasangan diskusinya untuk mencapai konsesus atas jawaban tersebut. (3) Share. Setelah berpasangan dalam tahap ini guru meminta siswa untuk berbagi jawaban yang mereka sepakati itu kepada semua siswa di kelas. Sesuai dengan tahapan-tahapan 
dan karakterisktik dari model pembelajaran kooperatif tipe Think Pair Share diatas, maka model pembelajaran ini dapat melatihkan beberapa karakter. Pada tahap Think dan Pair karakter jujur dan tanggung jawab dapat dimunculkan melalui kejujuran siswa dalam mengerjakan soal yang diberikan pada setiap tahapan dan tanggung jawab dalam menyelesaikan semua soal yang diberikan. Pada tahap Share karakter yang muncul adalah tanggung jawab atas hasil diskusi yang dilakukan dengan teman pasangannya. Sedangkan karakter disiplin bisa dilihat pada saat ketepatan waktu dalam masuk kelas dan dalam tepat waktu dalam pengumpulan tugas. Oleh karena itu, melalui model pembelajaran kooperatif Think Pair Share dapat menanamkan karakter-karakter yang baik dalam diri siswa masing-masing, serta dapat menumbuhkan kesadaran pribadi siswa untuk semangat belajar sehingga dengan demikian dapat meningkatkan hasil belajar siswa.

\section{Pengembangan Karakter Siswa yang Menggunakan Metode Konvensional}

Pada kelas yang tidak menggunakan model pembelajaran kooperatif tipe Think-Pairs-Share (TPS), suasana kelas terlihat monoton dan kaku. Guru menggunakan metode ceramah dalam menyampaikan materi pelajaran. Aktifitas siswa hanya sebatas mendengarkan materi yang disampaikan oleh gurunya. Kemudian siswa diminta oleh guru untuk mencatat materi yang telah dijelaskan oleh guru. Sesekali guru melemparkan pertanyaan kepada siswa berhubungan dengan materi yang telah disampaikan. Aktifitas pada kelas kontrol jauh dari kata aktif, hal itu dikarenakan guru tidak melakukan variasi dalam pembelajaran. Aktifitas siswa hanya mendengarkan, mencatat, dan mengerjakan latihan yang diberikan oleh guru.

Selama proses pembelajaran terlihat bahwa ada beberapa siswa yang ketika guru meminta untuk mencatat, mereka tidak mencatat materi yang dijelaskan oleh guru di buku catatan mereka, mereka juga tidak mendengarkan penjelasan guru secara serius, bahkan ketika guru meminta mereka mengerjakan latihan mereka lebih membebankan latihan itu kepada yang pintar saja, dan mereka lebih suka mencontek pekerjaan temannya daripada berusaha sendiri untuk menyelesaikan soal tersebut. Penerapan model pembelajaran dengan menggunakan metode ceramah, pada kenyataannya tidak mampu mengembangkan karakter siswa terutama karakter jujur, disiplin dan tanggung jawab. Hal ini terlihat ketika guru memberikan tugas atau pekerjaan rumah kepada siswa, masih banyak siswa yang tidak mengumpulkan atau mengumpulkannya tidak tepat pada waktunya. Pekerjaan rumah idak lagi dikerjakan dirumah tapi malah dikerjkaan disekolah sebelum jam pelajaran dimulai dengan mencontek pada teman yang bisa. Hal ini menunjukkan bahwa tidak adanya rasa tanggung jawab siswa terhadap tugas yang diberikan oleh guru. Ketidak jujuran siswa dalam prose pembelajaran juga terlihat ketika mereka ditanya kenapa tidak mengerjakan tugas, maka siswa lebih cenderung menjawab bahwa mereka lupa.

Metode ceramah yang digunakan oleh guru tidak mampu mengembangkan karakter siswa secara keseluruhan. Hal itu dikarenakan model pembelajaran secara ceramah tidak melibatkan siswa secara aktif, sehingga menyebabkan kurangnya rasa optimisme dalam diri siswa. Metode belajar secara ceramah tidak mampu menumbuhkan dan karakter jujur, disiplin, dan tanggung jawab kepada siswa. Ketika dilakukan penyebaran angket kepada siswa dengan 15 butir pernyataan, dengan skor yang telah ditentukan, diperoleh hasil bahwa skor rata-rata pengembangan karakter siswa yang menggunakan model pembelajaran dengan metode ceramah lebih rendah dibandingkan dengan skor rata-rata siswa kelas yang menggunakan model pembelajaran kooperatif tipe TPS.

\section{Perbedaan Pengembangan Karakter Siswa}

Perbedaan karakter antara siswa yang menggunakan model pembelajaran kooperatif tipe Think-Pairs-Share dengan siswa yang menggunakan metode ceramah dikarenakan adanya model pembelajaran yang diterapkan. Kelas yang pembelajarannya menggunakan model pembelajaran kooperatif tipe Think-Pairs-Share terlihat begitu aktif dan semangat dalam belajar. Langkahlangkah dalam model pembelajaran kooperatif tipe Think-Pairs-Share dapat menumbuhkan karakter jujur, disipilin, dan tanggung jawab terhadap siswa. 
Pembelajaran pada kelas yang tidak menggunakan model pembelajaran kooperatif tipe Think-Pairs-Share dilakukan dengan menggunakan metode ceramah, guru memegang kendali kelas dan menjelaskan materi pelajaran secara satu arah, dimana siswa diposisikan sebagai objek yang akan diberi informasi-informasi. Pembelajaran terkesan monoton dan kaku, siswa tidak aktif dalam pembelajaran. Kegiatan selama proses pembelajaran yaitu guru menjelaskan dan mencatat materi pada papan tulis, kemudian siswa mendengarkan penjelasan guru dan mencatat materi tersebut di buku catatan mereka, selanjutkan kegiatan pembelajaran dilanjutkan dengan guru memberikan latihan kepada siswa. Latihan yang diberikan oleh guru hanya bisa dikerjakan oleh siswa yang pintar saja, sedangkan siswa yang lain terlihat hanya berharap contekan dari siswa yang pandai. Kurang semangatnya siswa dalam proses pembelajaran ditambah lagi tidak ada keinginan dari siswa untuk bisa dan dapat mengerjakan soal latihan ynag diberikan oleh guru merupakan salah satu indikator kurangnya pengembangan karakter jujur, dispilin, dan tanggung jawab dalam diri siswa. Dari hasil analisa angket yang peneliti sebarkan kepada kedua kelas, diperoleh hasil bahwa terdapat perbedaan pengembangan karakter antara siswa yang menggunakan model pembelajaran kooperatif tipe Think-Pairs-Share dengan siswa yang tidak menggunakan model pembelajaran kooperatif tipe Think-Pairs-Share .

Perbedaan pengembangan karakter antara siswa yang menggunakan model pembelajaran kooperatif tipe Think-Pairs-Share dengan kelas yang tidak menggunakan model pembelajaran kooperatif tipe Think-Pairs-Share disebabkan oleh model pembelajaran yang digunakan oleh guru. model pembelajaran kooperatif tipe Think-Pairs-Share dapat meningkatkan rasa optimisme, percaya diri, rasa ingin tahu, dan semangat yang tinggi pada siswa dalam menggali pengetahuan mereka sehingga secara tidak langsung dapat membentuk karakter jujur, disiplin, dan tanggung jawab dalam diri siswa. Sedangkan pada kelas yang tidak menggunakan model pembelajaran kooperatif tipe Think-Pairs-Share, selama proses pembelajaran terlihat bawa siswa tidak memiliki rasa percaya diri, optimisme dan semangat yang tinggi untuk mencari tahu dan menggali informasiinformasi yang belum diketahuinya. Semangat yang rendah dan rasa ingin tahu yang kurang merupakan salah satu indikator kurangnya pengembangan karakter siswa.

\section{KESIMPULAN}

Berdasarkan pembahasan di atas, maka dapat disimpulkan bahwa:

1. Kemampuan pemahaman konsep matematis siswa yang menggunakan model pembelajaran kooperatif tipe Think-Pairs-Share lebih baik dibandingkan dengan kemampuan pemahaman konsep matematis siswa yang tidak menggunakan model pembelajaran kooperatif tipe ThinkPairs-Share dengan rata-rata 20,9. Hal itu dapat dilihat dari hasil penelitian, dari perhitungan statistik $\mathrm{t}$ diperoleh $\mathrm{t}_{\text {hitung }}=2,7$ dan $\mathrm{t}_{\text {tabel }}=1,53$ sehingga $\mathrm{t}_{\text {hitung }}>\mathrm{t}_{\text {tabel }}$.

2. Kemampuan pemahaman konsep matematis siswa yang tidak menggunakan model pembelajaran kooperatif tipe Think-Pairs-Share lebih rendah dibandingkan dengan kemampuan pemahaman konsep matematis siswa yang menggunakan model pembelajaran kooperatif tipe Think-Pairs-Share dengan rata-rata 16,75 . Hal itu dapat dilihat dari hasil penelitian, dari perhitungan statistik diperoleh $\mathrm{t}_{\text {hitung }}=2,7$ dan $\mathrm{t}_{\text {tabel }}=1,53$ sehingga $\mathrm{t}_{\text {hitung }}>\mathrm{t}_{\text {tabel. }}$.

3. Terdapat perbedaan kemampuan pemahaman konsep matematika siswa antara yanng menggunakan model pembelajaran kooperatif tipe Think-Pairs-Share dengan siswa yang tidak menggunakan model pembelajaran kooperatif tipe Think-Pairs-Share.

4. Karakter siswa yang menggunakan model pembelajaran kooperatif tipe Think-Pairs-Share lebih baik dibandingkan dengan karakter siswa yang tidak menggunakan model pembelajaran kooperatif tipe Think-Pairs-Share dengan rata-rata 65,2 . Hal itu dapat dilihat dari hasil penelitian, dari perhitungan statistik $\mathrm{t}$ diperoleh ${ }_{\mathrm{t} \text { hitung }}=2,64$ dan ${ }_{\mathrm{t}}$ tabel $=1,1,676$ Sehingga $_{\mathrm{t} \text { hitung }}$ $>_{\text {t tabel, }}$

5. Karakter siswa yang menggunakan model pembelajaran kooperatif tipe Think-Pairs-Share lebih baik dibandingkan dengan karakter siswa yang tidak menggunakan model pembelajaran kooperatif tipe Think-Pairs-Share dengan rata-rata 62,4 . Hal itu dapat dilihat dari hasil 
penelitian, dari perhitungan statistik $t$ diperoleh $t_{\text {hitung }}=2,64$ dan $t_{\text {tabel }}=1,1,676$ Sehingga $t_{\text {hitung }}$ $>t_{\text {tabel, }}$

6. Terdapat perbedaan karakter anatara siswa yang menggunakan model pembelajaran tipe ThinkPairs-Share dengan siswa yang tidak menggunakan model pembelajaran tipe Think-PairsShare.

\section{DAFTAR RUJUKAN}

Arikunto, Suharsimi. 2009. Dasar-dasar Evaluasi Pendidikan. Jakarta: bumi Aksara

Asma, Nur. 2012. Model Pembelajaran Kooperatif. Padang: UNP Press.

Erman, Suherman, dkk. 2003. Strategi Pembelajaran Matematika Kontemporer. Bandung: JICA universitas Pendidikan Indonesia.

E. Slavin, Robert. 2005. Cooperative Learning Teori Riset dan Praktik. Bandung: Nusa Media

Fathurrohman, Pupuh.2007. Strategi Belajar Mengajar. Bandung: PT Refika Aditama

Hamid, Hamdani.2013. Pendidikan Karakter Islam. Bandung: Pustaka Setia

Isjoni. 2011. Cooperatif Learning. Pekan Baru: Alfabeta

Kusmiati. 2011. Pembelajaran Kooperatif Untuk Meningkatkan Hasil Belajar Matematika Siswa kelas II SDN Rahayu Tahun Ajaran 2012/2013. Universitas Sebelas Maret.

Lie, Anita. 2003. Cooperatif learning mempraktekkan cooperatif Learning di Ruang-Ruang Kelas. Jakarta: Grasindo.

Nurhadi, dkk. 2004. Pembelajaran konstekstual (contekstual teaching and learning/CTL) dan penerapannya dalam KBK. Malang: Universitas Negeri Malang.

Oemar Hamalik.2008. Kurikulum dan Pembelajaran. Bandung: PT Bumi Aksara

Prawironegoro, Pratiknyo. 1985. Evaluasi Hasil Belajar Khusus Analisis Soal Untuk Bidang Studi Matematika. Jakarata: Fortuna

Purwanto, Ngalim.1990. Psikologi Pendidikan. Bandung: PT Remaja Rosdakarya

Rusman. 2010. Model-Model Pembelajran Mengembangkan Profesional Guru. Jakarta: Raja Grafindo Persada.

Sharan, Shlomo. 2009. Cooperatif Learning. Yogyakarta: Imperium

Slameto.2010. Belajar \& Faktor-Faktor yang Mempengaruhi. Jakarta: Rineka Cipta.

Suprijono, agus. 2009. Cooperatif Learning Teori\& Aplikasi Paikem. Yogyakarta: Pustaka Pelajar. Suryabrata, Sumadi. 1983. Metodologi Penelitian. Jakarta: PT Raja Grafindo Persada

Suyadi. 2012. Strategi Pembelajaran Pendidikan Berkarakter. Yogyakarta: PT.Remaja Rosdakarya Trianto. 2009. Mendesain Model Pembelajaran Inovatif Progresif. Jakarta: Prenada Media Group. 